UDC 811.111: 81'367.4

DOI https://doi.org/10.32841/2409-1154.2020.45-2.34

\author{
Talavira N.M., \\ Candidate of Philological Sciences, Associate Professor, \\ Associate Professor at the Department of Germanic Languages and Methods \\ of Teaching Foreign Languages \\ Nizhyn Mykola Gogol State University
}

\author{
Nikitenko I. I., \\ Master Student \\ Nizhyn Mykola Gogol State University
}

\title{
VERBALIZATION OF MODERN GENERATIONS IN ENGLISH NEWS TEXTS: LINGUO-RHETORICAL APPROACH
}

Summary. The purpose of the article is to study linguistic units verbalizing modern generations in English news texts. The investigation of modern generations presupposes characterizing, description and comparison of the main aspects of existence of four of them: baby-boomers (born in 1943-1960), generation X (born in 1965-1980), generation Y (born in 1984-2000) and generation $Z$ (born since 2000). In 68 news texts we have singled out 240 constructions, i. e. the pairing of form, meaning and function. Constructions exist as prefabricated patterns entrenched in human's mind in a ready-made form to be contextually used in various communicative situations.

The selected constructions have been divided into groups on the basis of rhetorical approach, while rhetoric is viewed as a means of influence on the addressee and text organization with the help of linguistic units.

The usage of constructions denoting modern generations is represented by strategies and tactics of text structuring with reference to basic human needs. These needs include: physiological, safety needs, belongingness, esteem need and need of self-actualization. The strategy appealing to the first group of needs is represented by the tactic of their satisfying only in texts about zoomers while the other three generations are designated as those suffering from insomnia, poverty and unhealthy lifestyle. The strategy concerning security is reflected by the tactic of safety loss for boomers and millennials and by safety renewal for Xers and zoomers. In the strategy appealing to belongingness the tactic of belonging to family is dominant for Xers and millennials, while the tactic of belonging to global community is prevalent for boomers and zoomers. In the strategy concerning esteem the tactic of high level of reputation is topical only for generation $\mathrm{Z}$ and the other three generations are reflected as scornful, egoistic, indolent and haughty. According to the strategy of self-actualization the tactic of development is typical of all described generations as they are keen on state-of-the art technologies, aimed at career growth and self-development.

Key words: generation, construction, basic need, strategy, tactic, English news text.

Introduction. The variety of opinions and attitudes between people of different age groups concerning every aspect of our existence has always been attributed to the notion of generation gap. To explain the notion of modern generations, it is to be mentioned that generation is a demographical cohort, i.e. a group of people that were born and lived simultaneously [10]. The peculiarities of all these groups were created by the influence of certain historical, political and economic events. The notion of modern generation refers to cohorts that are living at the present time, namely: Generation of baby-boomers (born in 1943-1960), Generation X (born in 1965-1980), Generation Y or Millennials (born in 19842000) and Generation Z (born since 2000) [9]. It is to be noted that the years of birth of every of them differ depending on the territory, opinions of the researchers, etc.

Modern generations have been studied by many scientists including, Monhollon [11], Slakva [3], Vostretsova [1]. They claim that generation of baby boomers includes hard-working people who appreciate having families, supporting each other, resisting everything that is in contrast to their inner visions and despite their age try to fit into the modern way of living [11]. Generation $\mathrm{X}$ are described as self-efficient people flexible and well-informed, relying on themselves and refusing to accept values produced by previous generations [3]. Millennials, to their minds, are well educated people, addicted to technologies, especially to social media, impatient, intransigent, indolent to work, and dependent on people's opinions [1]. As for the youngest generation, it is characterized by addiction to techs, intelligence, diversity, a healthy lifestyle though they are hot-tempered and dependent on others [3]. However, though peculiar features of each demographical cohort have been thoroughly studied, the general image of modern generations in media has been on the periphery of linguistic interest.

The topicality of the paper is broughtabout by the general tendency in modern linguistics to analyze different ways of communication, on the one hand, and linguistic units, reflecting various phenomena and events, on the other hand. News texts as the main components of media discourse are a valuable source of investigating nominative units verbalizing four modern generations.

The paper aims at studying linguistic means, namely constructions, used in English news to designate modern generations. The work is intended to solve the following tasks: 1) to describe types of constructions implicated for nomination; 2) to analyze constructions used to describe modern generation; 3) to represent strategies and tactics of text structuring with reference to human basic needs.

The investigation of different aspects of four modern generations is done by analyzing their representation in news discourse. News stories, characterized by collective authors and mass audience, are 
studied from different perspectives. One of them is the rhetorical approach. It is generally known that rhetoric "is an acquired competence" and "a manner of thinking", which can provide possibilities for persuasion, conviction, action, or judgments [6, p. 17]. To analyze verbalization of modern generations in news texts we will take into consideration the persuasive aspect of classical rhetoric [5, p. 5], new rhetoric approach which views rhetoric as a science and semiotic approach laying emphasis on specific ways of language use $[2,10]$, which help the speaker to have influence on the audience.

The materials of our investigation consists of 68 news stories from various English news sites like BBC, CNN, Entrepreneur, USA Today, The New York Times, etc. In news stories modern generations are described by particular linguistic units, namely constructions. Construction is defined as correspondence of form, meaning and function [7, p. 29]. The classification that is chosen divides constructions into immediate that consists of 2 independent words, e. g. demographical cohort, modified that adds units to the immediate one, e.g. modern demographical cohort, and extended one that consists of 2 immediate constructions, e. g. investigate modern demographical cohort [see: 12, p. 102]. To study modern generations 240 constructions have been selected: the Generation of boomers $49(20,4 \%)$ pairings, Generation X - $54(22,5 \%)$ constructions, Millennials - $69(28,8 \%)$ units and Generation Z- 68 (28,3\%) constructions.

All of the selected constructions are divided into groups that represent strategies and tactics of text structuring. In media discourse, strategy is used to construct the events presented in the content blocks of the news stories while tactics are defined as specific speech actions, ensuring that the addressee achieves the goal of communication $[4, \mathrm{p} .60]$. The strategies for representing generations are created with the reference to basic human needs [8, p. 372]. They are organized in a form of hierarchy: physiological needs (food, sleep, shelter etc.), safety needs (security of employment, health and property), love and belongingness needs (being a part of society), esteem need (evaluation and respect) and self-actualization (development). As the result such 5 strategies and corresponding tactics have been formulated:

- strategy appealing to physiological needs is represented by the tactics of satisfying and neglecting physiological needs;

- strategy concerning safety needs includes tactic of potential threat, tactic of safety loss, tactic of safety renewal;

- strategy appealing to belongingness is rendered by tactic of belonging to global community, tactic of belonging to family and tactic of belonging to closely integrated community;

- strategy concerning esteem has tactics of high and low levels of reputation;

- strategy of self-actualization includes tactic of development and tactic of its lack.

Strategy appealing to physiological needs. It has been found that all of the generations except Gen $\mathrm{Z}$ are verbalized in news text with the help of the tactic of neglecting physiological needs. Boomers ignore them because of starvation, insomnia and poverty, e.g. Pensioners live in deep poverty [10]. Gen X suffers from unhealthy lifestyle, lack of housing and poverty, e. g. Gen $X$ is the first generation not meeting the living standards [1]. Millennials are represented by this tactic due to notable problems including junk food passion, obesity, lack of housing and money and low sexual desire, e.g. Millennials set to be fattest generation [6]. However, zoomers are represented by the tactic of satysfying physiological needs due to healthy lifestyle, saving money for housing, renting clothes and beneficial attitude to intimacy, e. g. More Gen Z is using food as medicine, NPD says [2].

Strategy concerning security needs. For boomers and millennials, the tactic of safety loss prevails. As for boomers, they suffer from deathly illnesses i.e. cancer, alcohol and drug misuse, coronavirus, heart diseases, and lack of money, e. g. For a group that's considered very high risk for contracting coronavirus, they're carrying on life as usual [14]. Talking about millennials, they struggle with Covid-19, mental fog and mental health diseases, financial instability and online fraud, e. g. "About $80 \%$ of millennials are going to experience a mild or asymptomatic version of Covid. It's the other $20 \%$ that we're worried about", said Dr. Luis Ostrosky-Zeichner [9]. Gen X and Gen Z are characterized by the tactic of safety renewal. The reason for Xers is because of their desire to improve their health by seeking and getting help and external measures taken to lower amount of suicide cases, e. g. Generation $X$ is seeking help [5]. Gen Z is represented by earnest attitude to health and environment, accuracy towards techs usage and spending money, e. g. With Gen $Z$ we expect to see a greater level of engagement with in-home activism, such as trying to reduce food waste", said Dr Lilly Da Gama [4].

Strategy appealing to belongingness. In news about boomers and zoomers, tactic of belongingness to global community prevails. Boomers are characterized by having feelings of isolation and loneliness and deficiency of interaction, e. g. Baby-boomers may have a symptom of other problems, such as loneliness and isolation [5]. As for zoomers, significant opinions toward politics, tackling inequity and demonstrating identity are taken into account, e. g. Gen Zers are also fed up with the longstanding history of inequity in our society [3]. In news about Gen X and Millennials tactic of belongingness to family prevails. The lockdown has made Xers responsible for ageing parents' wellbeing and children's homeschooling. Moreover, the described generation is the only one who benefits from being isolated, e. g. Xers are raising children, and at the same time caring for their ageing parents [13]. As for millennials, they are the first who mention external and internal reasons for incomprehension of necessity of having a family, e. g. Getting married and having babies in one's thirties and forties is more common among this generation. Millennials do such things later [7].

Strategy concerning esteem. As for the esteem need, the first three generations are represented in news with low level of reputation. Boomers are described as disrespectful, scornful, hassled and misunderstanding, e. g. Boomers are playing video games as a way to remain socially connected and cognitively sharp in a world that continues to expand into the digital realm [11]. Xers are described as being indolent, screwed and hesitant, e.g. Gen $X$ are influenced by career ambition, economic challenges and changing mores and life choices [1]. As for millennials, they are designated as indolent to work, selfish and struggling, e. g. Millenials think that international exposures actually help them to learn new skills [12]. However, the Gen Z in reflected with high level of reputation as they are creative, educated people, more diligent and aspiring, e. g. The world as zoomers know it has been blighted by financial, economic and environmental turmoil and they want to make a change [8].

According to the strategy of self-actualization all of the generations are presented from the perspective of tactic 
of development. Boomers are shown as the developed generation due to their usage of up-to-date technologies, discovering world and contributing to cognition, e.g. Boomers are playing video games as a way to remain socially connected and cognitively sharp in a world that continues to expand into the digital realm [11]. As for X-ers, they are represented as well-developed, flexible, forceful cohort with the fascinating career perspectives, e. g. Gen $X$ are influenced by career ambition, economic challenges and changing mores and life choices [1]. Millennials are said to have opportunities for professional growth, developing skills and broadening knowledge. Moreover, this generation is the one who profits from international experience, e. g. Millenials think that international exposures actually help them to learn new skills [12]. Talking about zoomers, despite their young age they are motivated, active, inventive and focused on improving themselves, e. g. The world as zoomers know it has been blighted by financial, economic and environmental turmoil and they want to make a change [8].

Conclusions. News texts about modern generations are structured by five strategies appealing to basic human needs. Strategy appealing to physiological needs is represented by the tactic of their satisfying only in texts about zoomers. Strategy concerning security is designated by the tactic of safety loss for boomers and millennials and by the one of safety renewal for Xers and zoomers. In the strategy appealing to belongingness the tactic of belonging to family is dominant for Xers and millennials while the tactic of belonging to global community is prevalent for boomers and zoomers. In the strategy concerning esteem the tactic of high level of reputation is topical only for boomers while the strategy of self-actualization is represented by the tactic of development for all of the described generations. Further investigation can go in two directions: on the one hand, we can focus on other media, namely social networks, on the other hand, we can implicate conceptual metaphor to analyse representation of modern generations.

\section{References:}

1. Вострецова А. Наука и образование на современном этапе развития: опыт, проблемы и пути их решения. Москва : Мир науки, 2017. 490 c.

2. Клюев Е. Риторика. Инвенция. Диспозиция. Элокуция : учебное пособие для высших учебных заведений. Москва : ПРНОР, 2001. 272 с.

3. Слаква Ю. Теорія поколінь (х, у, z). URL: https://learning.ua/ blog/201711/teoriia-pokolin-х-y-z/ (дата звернення: 10.12.2020).

4. Талавіра Н. Безартиклеві прийменникові звороти сучасної англійської мови: когнітивно-дискурсивний аспект : дис. ... канд. філол. наук: 10.02.04. Ніжин, 2015. 225 c.

5. Aristotle. Rhetoric. New York : Cosimo Books, 2010. 194 p.

6. Farrell T.B. Norms of Rhetorical Culture. New Haven : Yale University Press, 1995. 384 p.

7. Goldberg A.E. Explain Me This. Creativity, Competition, and the Partial Productivity of Constructions. Princeton : Princeton University Press, 2019. 216 p.

8. Maslow A.H. Motivation and Personality. New York : Harper \& Row Publishers, 1970. $368 \mathrm{p}$.

9. McKay K., McKay B. How the generational cycle of history explains our current crisis. URL: https://www.artofmanliness.com/ articles/strauss-howe-generational-cycle-theory/ (дата звернення: 12.12.2020).

10. Merriam-Webster Dictionary. URL: https://www.merriam-webster. com/dictionary/ethos (дата звернення: 14.12.2020).

11. Monhollon R.L. Baby Boom : People and Perspectives. California : ABC-CLIO, 2010. $246 \mathrm{p}$.
12. Talavira N. English orientating constructions denoting location : classification and article use. Lingua Posnaniensis. №59 (2). P. 101-120.

\section{Illustration sources:}

13. Bindley K. Gen X Women Succeed at Work, Have Fewer Kids : Study. HuffPost : website. URL: https://www.huffpost.com/entry/gen-xstudy_n_959256 (дата звернення: 06.09.2020).

14. Danley S. More people than ever are using food as medicine, NPD says. Food Business News : website. URL: https://www.foodbusinessnews. net/articles/14386-more-people-than-ever-are-using-food-asmedicine-npd-says (дата звернення: 14.11.2020).

15. Gergen D., Cohen C. The next Greatest Generation. CNN : website. URL: $\quad$ https://edition.cnn.com/2020/06/14/opinions/black-livesmatter-gen-z-greatest-generation-gergen-cohen/index.html (дата звернення: 09.09.2020).

16. Grylls B. Gen Z's food FOMO is driving food waste. New Food Magazine : website. URL: https://www.newfoodmagazine.com/ news/122970/food-waste/ (дата звернення: 14.11.2020).

17. London millennials shunning the pub for the gym. BBC News : website. URL: https://www.bbc.com/news/av/uk-england-london-45836991/ london-millennials-shunning-the-pub-for-the-gym (дата звернення: 07.09.2020).

18. Millennials are set to become the "Fattest Generation" so good going, everyone. Mandatory Editors : website. URL: https://www.mandatory. com/living/1374505-millennials-set-become-fattest-generation-goodgoing-everyone (дата звернення: 07.09.2020).

19. Newman S. Should we worry about millennials not having babies? Psychology Today : website. URL: https://www.psychologytoday. com/us/blog/singletons/201804/should-we-worry-about-millennialsnot-having-babies (дата звернення: 07.09.2020).

20. Povah C., Vaukins S. Generation Z is starting university - but is higher education ready? The Guardian : website. URL: https://www. theguardian.com/higher-education-network/2017/jul/10/generationz-starting-university-higher-education-ready (дата звернення: 09.09.2020).

21. Prior R. Young Covid-19 survivors warn they're still suffering. $C N N$ : website. URL: https://edition.cnn.com/2020/07/18/health/long-termeffects-young-people-covid-wellness/index.html (дата звернення: 07.09.2020).

22. Roberts Y. Millennials are struggling. Is it the fault of the baby boomers? The Guardian : website. URL: https://www.theguardian. com/society/2018/apr/29/millennials-struggling-is-it-fault-of-babyboomers-intergenerational-fairness (дата звернення: 01.09.2020).

23. Rosenblatt K. Older people are embracing video games - and for some, stardom. Euronews : website. URL: https://www.euronews. com/2019/08/29/older-people-are-embracing-video-games-somestardom-n1047906 (дата звернення: 01.09.2020).

24. Shameem S. Here's What Millennials Want from Their Jobs. Entrepreneur : website. URL: https://www.entrepreneur.com/ article/331111 (дата звернення: 07.09.2020).

25. Storey S. Why Gen X women aren't sleeping. Huff Post : website. URL: https://www.huffpost.com/entry/why-we-cant-sleep-ada calhou n_n_5e0f9520c5b6b5a713ba0fc7 (дата звернення: 06.09.2020).

26. Valdes R. Even with a pandemic, many older Americans are carrying on as usual. CNN : website. URL: https://edition.cnn.com/2020/04/06/ us/older-people-coronavirus-invincible-high-risk-wellness-trnd/index. html (дата звернення: 01.09.2020).

Талавіра Н., Нікитенко І. Вербалізація сучасних поколінь в англомовних новинних текстах: лінгвориторичний аспект

Анотація. Метою поданої розвідки є вивчення мовних одиниць, що вербалізують сучасні покоління в англомовних новинних текстах. Вивчення сучасних 
поколінь включає характеристику, опис та порівняння основних аспектів існування чотирьох груп: бейбібумерів (народжені в період 1943-1960 роки), покоління X (народжені в період 1965-1980 роки), покоління Y (народжені в період 1984-2000 роки) та покоління Z (народжені із 2000 року). У 68 англомовних новинах було виокремлено 240 конструкцій, тобто мовних одиниць, які $€$ поєднанням форми, значення та функції. Конструкції укорінені в людську свідомість як паттерни, готові до контекстуально зумовленого вживання в різноманітних комунікативних ситуаціях.

Виділені конструкції були розділені на групи 3 урахуванням риторичного інструментарію, адже риторика тлумачиться як спосіб упливу на аудиторію й організацію текстів через уживання мовних одиниць.

Уживання конструкцій на позначення сучасних поколінь уособлюють стратегії та тактики структурування текстів $з$ опертям на базові потреби людини. Базовими називають такі 5 потреб: фізіологічні, потреба в безпеці, у приналежності та любові, у повазі, потреба в самоактуалізації. Стратегія апелювання до першої групи потреб представлена тактикою їх задоволення лише в покоління зумерів, тоді як три інші покоління подані як такі, що страждають від безсоння, бідності та нездорового способу життя. Стратегія безпеки бумерів та міленіалів представлена тактикою іiі втрати, тоді як в інших поколінь тактикою її відновлення. У стратегії приналежності тактикою, що домінує, для покоління X та міленіалів є ставлення до сім'ї, а для інших - належність до світової спільноти, оскільки бумерам притаманне відчуття самотності, а зумерам - активна політична позиція й участь у житті країни. Стратегія потреби в повазі представлена тактикою гарної репутації лише для покоління Z, тоді як перші три покоління подані в новинах як презирливі, егоїстичні, ліниві, зверхні. Структурація текстів згідно зі стратегією самоактуалізації представлена тактикою розвитку, оскільки всі покоління подані як такі, що цікавляться сучасними технологіями, націленими на кар'єрне зростання та самовдосконалення.

Ключові слова: покоління, конструкція, базова потреба, стратегія, тактика, англомовний новинний текст. 